\title{
Effect of Hibiscus sabdariffa and Ceratonia silique aqueous Extracts on the Reproductive Hormones of Diabetic Male Rats
}

\author{
Asmaa M.I.El Gamel $^{1}$, Alaa Osama Aboraya ${ }^{2}$ \\ ${ }^{1}$ Fellow (Lecturer) of Nutrition and Food Science, Ahmed Maher Teaching \\ Hospital, Egypt. \\ ${ }^{2}$ Nutrition and Food Science Dept., Faculty of Home Economics, Helwan \\ University.
}

\begin{abstract}
The influence of aqueous extract of Hibiscus sabdariffa calyx and Ceratonia silique on feed intake, body weight gains, feed efficiency ratio, blood glucose, lipid profile, serum fertility hormones in diabetic rats were examined. Thirty Sprague-Dawley adult male rats were divided into six similar groups. Group (1) fed on basal diet and used as a negative control group, While the other rats $(\mathrm{n}=25)$ injected with $(120 \mathrm{mg}$ alloxan/kg b.w. daily) "intraperitoneal injection" for three days to induce diabetes. The second group was then maintained diabetic (positive control) and the other four groups were given $2 \mathrm{ml}$ orally from condensed and diluted Hibiscus sabdariffa calyx and Ceratonia silique aqueous extracts which provided each rat with active component resulted from $100 \mathrm{mg}$ and $200 \mathrm{mg} / \mathrm{kg}$ respectively. At the end of the experimental period, blood samples were collected from each rat and separate the serum which used for determination of some biochemical analyses. Tests and pancreas specimens were taken for estimating histopathology. The high active component found in concentrated Hibiscus sabdariffa calyx extract. The findings revealed that administration of Hibiscus sabdariffa calyx and Ceratonia silique aqueous extracts orally to rats with diabetes, non-significant changes in body weight gains, feed efficiency ratio, feed intake and decreased serum lipid profile, except HDL-c. Administration of Hibiscus sabdariffa calyx and Ceratonia silique aqueous extracts decreased glucose level. It also increased in fertility hormones serum Testosterone, Folicle Stimulating Hormone, Luteinizing Hormone in diabetic rats. Through these results and histopathology examinations illustrate the positive impact of both Hibiscus sabdariffa calyx and Ceratonia silique aqueous extracts in tests and pancreas. These findings point to the future opportunity for usage Hibiscus sabdariffa calyx and Ceratonia silique aqueous extracts for the treatment of infertility diabetic patients.
\end{abstract}

Keywords: Hibiscus; Ceratonia; Fertility Hormones; Diabetes; Lipid profile; Antioxidant; Rats. 


\section{Introduction}

Diabetes mellitus (DM) is a widespread metabolic disorder that is predicted to affect six hundred and forty million people by 2040 (International Diabetes Federation, 2016). DM occurs as a result of a deficiency in insulin secretion, insulin action or together resulting in increased blood glucose (GamboaGómez et al., 2017). Hibiscus sabdariffa $L$. has traditionally been used as food, in herbal beverages, medicine industries in hot and cold drinks, as a flavoring agent ( Inês Da et al.,2014)

Diabetes mellitus plays a very significant role in the effect of oxidative damage on male sexual dysfunction and infertility. The normal antioxidant properties of Hibiscus sabdariffa extract (HSE), as shown in experimental studies (Md Idris et al., 2013). The assumptive role of polyphenols in the prevention or even treatment of diabetes and complications associated with diabetes has been defined in a series of studies. The antidiabetic action proposed by polyphenols is based on reducing the intestinal absorption of dietary carbohydrates, improving insulin release and insulin sensitivity and reducing inflammation and oxidation (Hanhineva et al., 2010). New studies have showed that aqueous extract of rosella calyx has the ability to protect against sperm damage caused by diabetics (Md Idris et al., 2012). Polyphenols causing up regulation of glucose transporters in the skeletal muscle, thereby reducing glucose in the blood levels in rats with diabetes and also work Rising glucose absorption (Kim et al., 2016).

Natural antioxidant products may be effective for alternative or complementary treatment of diabetes and its complications. Hibiscus sabdariffa Linn among others. (HS) is an important source of conventional medicinal products (Ubani et al., 2010). Hibiscus sabdariffa extract (HSE) contains flavonoids shown to be antifertile, hypoglycemic in these compounds ( Neeru and Sharma.,2008). The fresh leaf aqueous extract of Hibiscus sabdariffa extract (HSE) has anabolic and virilizing effect as shown by rised serum testosterone levels in male rats (Moundipa et al., 1999).

Hibiscus sabdariffa extract has used as a medicinal herb to treat different illnesses. The 28-day administration of Hibiscus sabdariffa $L$ aqueous extract is associated with lower plasma levels of testosterone, luteinizing hormone, follicle-stimulating hormone and prolactin in male rat comparison with control group ( Nwabufo and Olusanya, 2017). Ceratonia siliqua L. (Family Leguminosae) is an evergreen tree and naturally grown in the Mediterranean area ( Rejeb, 1995). 
Carob extract is a rich source of anti-diabetic and anti-oxidant agents, including gallotannins, flavonoids and other relevant polyphenols (Marghoob and Abdelmarouf, 2016). Aqueous extracts from carob pods show high antioxidant activity and free radical scavenging activity (RSA) and effect of carob pod aqueous extract (ICPAE) in reducing the absorption of intestinal glucose and in vivo treating high blood sugar and symptoms of alloxaneinduced diabetes Rtibi et al.,(2015). Carob extract impacts on male fertility. Carob's effects on testicular structure, sperm quality, and testosterone hormone levels In rats with infertility (Azadeh et al.,2018). Antibacterial, anti-cancer, anti-diabetic and good antioxidant properties of carob extract ( Rtibi et al.,2017). Extract use at high doses increases Sperm abundance in tubules of seminiferous origin ( Mokhtari et al.,2012). Carob pod aqueous extract (ICPAE) showed significant reductions in glucose in the blood and biochemical profiles in rats with diabetes by different doses Rtibi et al., (2017).

There have been reports of different medicinal plants and their extracts being effective in treating diabetes. These are rich sources of anti-diabetic and anti-oxidant agents such as flavonoids, gallotannins and other polyphenols associated with them. Carob tree is rich in polyphenols and flavonoids Marghoob and Abdelmarouf,(2016).

The present research was therefore intended to assess the effect of aqueous extracts of Hibiscus sabdariffa and Ceratonia silique on the reproductive hormones of diabetic male rats.

\section{Materials and Methods}

\section{Materials}

- Dried Hibiscus sabdariffa Linn, Ceratonia siliqua L,oil and starch were purchased from local market, Cairo, Egypt.

- Casein, vitamins, minerals, cellulose, choline chloride and alloxan were purchased from El-Gomhoreya Company, Cairo, Egypt.

- Thirty male albino rats (Sprague Dawley Strain) were obtained from Food Technology Res. Institute, Giza.

\section{Methods}

\section{Preparation of aqueous extract of Hibiscus sabdariffa calyx and Ceratonia silique}

Dried HSc and CS (100and 200g) were boiled in $1 \mathrm{~L}$ of distilled water for 15 min. The boiled sample was allowed to cool and then filtered into a sterile bottle and refrigerated ( Nwabufo and Olusanya, 2017). 


\section{Estimation of total content of phenols and flavonoids}

Total phenols and flavonoids in aqueous extract of Hibiscus sabdariffa calyx and Ceratonia silique were outlined by Singleton et al., (1999) \& Joyeux et al.,(1995),respectively.

\section{Experimental design}

Male albino rats Spargue Dawley Strain (30 rats) weighing (150 -170 g) were kept in individual stainless steel cages under hygienic conditions and fed one week on basal diet according to Reeves et al ., (1993) for adaptation at ad libitum in the animal house of Agricultural Res. Center in Ministry of Agriculture ), Giza. The basal diet consisted of casein 14\%, cellulose 5\%, corn oil $4 \%$, salt mixture $3.5 \%$, vitamin mixture $1 \%$ and the remained amount is corn starch according to Reeves et al ., (1993).

After the adaptation period, the experimental animals were divided into 6 groups, each group contained (5) animals:

The $1^{\text {st }}$ group (normal group), rats fed on basal $\operatorname{diet}(B . D)$, while the other five groups were given alloxan by intraperitoneal injection of a single daily dose of $120 \mathrm{mg} / \mathrm{kg}$ for 3 days to induce moderate stable diabetes as described by Ashok et al,(2007). The $2^{\text {nd }}$ group of rats was left as diabetic control.Diabetic rats of the $3^{\text {rd }}, \mathbf{4}^{\text {th }}$ and $\mathbf{5}^{\text {th }}, \mathbf{6}^{\text {th }}$ groups were fed on (B.D) and treated daily orally with(2 $\mathrm{mg} / \mathrm{kg}$ ) body weight of aqueous extract of Hibiscus sabdariffa calyx and Ceratonia silique.

aqueous extract of Hibiscus sabdariffa calyx and Ceratonia silique were given orally to the rats through a gastric tube.

During the experimental period (30 days), each rat was weighed every week and food consumption was recorded. The body weight gain\% (BWG\%) and food efficiency ratio (FER) were estimated outlined by Chapman $\boldsymbol{e t}$ al., (1959) .

At the end of the experimental period rats were fasted over night before sacrificing blood was collected then centrifuged. Serum was separated and stored at $-20^{\circ} \mathrm{c}$ for biochemical analysis i.e. serum total cholesterol(TC) and triglycerides(TG) Schettler and Nussel, (1975), high density lipoprotein cholesterol (HDL-c) Lope Virella et al., (1977), low- density lipoprotein cholesterol (LDL-c ) and very low density lipoprotein- cholesterol (VLDL-c) Fried wald et al., (1972), Serum glucose (Trinder,1969), serum Testosterone(T) Wilke and Utley, (1987), Lutenizing hormone(LH) and Folicle stimulating hormone(FSH) Uotila et al.,(1981) and Prolactin(PRL) Tietz , (1995).

\section{Histopathological Examination}

Pancreas and testes were separated from each rat and examined histopathologicaly Bancroft et al., (2012). 


\section{Statistical analysis}

The results were expressed as means \pm SD statistically analyzed using oneway (ANOVA) test $(\mathrm{p}<0.05)$ was used to signal significance Steel and Torri, (1980).

\section{Results and Discussion}

Tabulated data in Table (1) presented the total phenols and total flavonoids of Hibiscus sabdariffa calyx and Ceratonia silique aqueous extract which a high active component found in concentrated Hibiscus sabdariff calyx extract.Our results agree with Hirunpanich et al., 2006 and Tsai et al.,( 2002) these researchers cleared that aqueous extract of HS is enriched with high levels of antioxidants, primarily flavonoids. Also Tzu et al.,(2007) who reported that chemical constituents of Hibiscus sabdariffa $L$ which are antioxidant. Such as flavonoids and polyphenols are very high.

The results in Table (2) discovered that the positive control group non significantly in the feed efficiency ratio, feed intake and body weight gain $\%$ comparison to negative control rats. Oral aqueous extract of Hibiscus sabdariffa calyx and Ceratonia silique to diabetic rats caused no significant in the feed efficiency ratio, body weight gains and feed intake compared to positive control group .The results are non-agree with Andallu et al.,(2009) which found that animals receiving aqueous carob pod extract (ICPAE) raised their bodyweights relative to diabetic rats. ICPAE's potential to correct body and weight loss. Additionally, (Orisakwe et al .,2004 and Mahmoud, 2012) reported that diabetic rats treatment with Hibiscus sabdariffa extract (HSE) led to only a small elevation in body weight during the experiment. Our results agreement with (Qasem et al., 2018) stated that body weight at low- dose Ceratonia siliqua extract treated (500) $\mathrm{mg} / \mathrm{kg}$ and high- dose Ceratonia siliqua extract treated (1000) $\mathrm{mg} / \mathrm{kg}$ reduced significantly more than the untreated type 2 diabetic rats.

Serum analysis revealed that, significantly decrease in high- density lipoprotein, increase in low- density lipoprotein, very- low density lipoprotein, total cholesterol, triglycerides and glucose in the positive control group, comparison with negative group. Oral of aqueous extract of Hibiscus sabdariffa calyx and Ceratonia silique. to diabetic rats caused significant decreases (LDLc), (VLDL-c), (T.C), (T.G) and glucose, while increased in (HDL-c) compared to positive control group, in a dose dependent manner, as shown in Table (3) and Table (4) .Our results agree with Joanne, (2013) who cleared that Aqueous extract of the carob pod contains a high levels of polyphenols. These compounds have different physiological effects, involves improved digestion and reduction of cholesterol in surem and glucose levels. Also (Puro et al., 2014 and Si et al., 2017) said that Carob pod aqueous extract antihypertensive, 
hypolipidemic and hepatoprotective properties. (Peng et al., 2011) showed that The protective role of the Hibiscus sabdariffa polyphenol extract was tested in the diabetic rat model type II . The extract displayed anti-insulin resistance properties at a dosage of $200 \mathrm{mg} / \mathrm{kg}$, because it decreased hyperglycaemia and hyperinsulinemia. This reduced serum TG, cholesterol, and the lipoprotein / high-density protein ratio (LDL / HDL).Another study by Ochani \& Mello, 2009 and Yang et al., ( 2010) revealed that Low-density lipoprotein cholesterol, triglycerides , (TC), and lipid peroxidaxion in vivo were reduced by extracts of Hibiscus sabdariffa. Some even reported that the extract could also reduce serum (VLDL-c) along with an elevation in the serum level of highdensity lipoprotein cholesterol . Qasem et al.,(2018)found that the low dose of Ceratonia siliqua extract treated (500) $\mathrm{mg} / \mathrm{kg}$ reported a lower level of fasting blood glucose than untreated type 2 rats with diabetes at the end of the " 4 th" week, while the high dose of Ceratonia siliqua extract treated (1000) $\mathrm{mg} / \mathrm{kg}$ showed a lower level of FBG than untreated type 2 diabetic rats at the end of the 3rd and 4th weeks.

Data in Table (5) showed that positive control group significantly reduced serum Luteinizing Hormone, Testosterone, Folicle Stimulating Hormone and significantly increased in Prolactin comparison with negative group. Oral of aqueous extract of Hibiscus sabdariffa calyx and Ceratonia silique. to rats with diabetes Triggered significant increase in serum Testosterone, Folicle Stimulating Hormone, Luteinizing Hormone, while significantly reduced in Prolactin as compared with positive diabetic group.Our results agreed with Md Idris et al.,(2013) who said that the level of follicle-stimulating hormone (FSH) in the diabetic+ Hibiscus sabdariffa extract group was significantly elevation $(p<0.05)$ than of rats with diabetes, the level of testosterone in the diabetic+HSE group was slightly higher than in the diabetic group and Our results non agreed with Md Idris et al.,(2013) who reported the level of the luteinizing hormone (LH) was Significantly lower in the diabetic+HSE group than in rats with diabetes. The present result was in accordance with (Mohammadi et al.,2016)who showed that effect of various dosages of carob extract on testosterone hormone levels and testis histopathology in male adult mice is suggested for future research. In another study, found that carob extract intake caused a significantly higher in testosterone, and amount of LH decreased in experimental groups receiving 150 and $300(\mathrm{mg} / \mathrm{kg}$ ) extract, and non- significant changes were observed in FSH concentrations. Additionally, sperm density in seminiferous tubules has been increased in response to medium to high extract dosages (Mokhtari et al.,2012). The reduction of 250 mg Hibiscus sabdariffa extract in serum prolactin after twenty eight days of 
oral can be traced to the activity of prolactin hormone-inhibiting ( Nwabufo \& Olusanya , 2017).

\section{Histopathological Examinations}

\section{Examination of pancreas Histopathologically.}

Pancreas rats from group 1 (control negative) shown normal pancreatic acini and normal islets of Langerhan's (Figs. 1). In contrary, pancreas of rats from group 2(control positive) showed vacuolations of cells of islets of Langerhan's with pyknosis of their nuclei (Figs. 2), dilatation of pancreatic duct and inflammatory cells infiltration. However, pancreas of rats from groups $3,4 \& 5$ Hibiscus sabdariff calyx extrac $(100,200 \mathrm{mg} / \mathrm{kg}) \&$ Ceratonia silique extract $(100 \mathrm{mg} / \mathrm{kg})$ showed improved picture, examined sections from those groups showed only vacuolations of some cells of islets of Langerhan's (Figs. 3, 4\&5). Meanwhile, some examined sections from group 6 Ceratonia silique extract $(200 \mathrm{mg} / \mathrm{kg})$ revealed no histopathological alterations (Fig. 6), whereas, other sections showed only vacuolations of some cells of islets of Langerhan's. Our findings agree with Kasote et al., (2015) which indicated that low dose Ceratonia siliqua extract treated $(500) \mathrm{mg} / \mathrm{kg}$ and higher dose of Ceratonia siliqua extract treated (1000) $\mathrm{mg} / \mathrm{kg}$ still had active insulin secreting cells, This may be confirmed in a higher number of cells observed in low-dose pancreatic histological parts of Ceratonia siliqua extract -treated and high-dose Ceratonia siliqua extract treated compared with untreated type 2 diabetes. Additionally, (Ballester et al., 2004) revealed that (HSE) is most likely capable of regenerating $\beta$-cells in the pancreatic state.

\section{Examination of Testis Histopathologically.}

Microscopically, testis of rats from group 1 (control negative) showed the normal histological structure of seminiferous tubule with normal spermatogoneal cells and complete spermatogenesis (Figs. 1). In contrary, examined sections from group 2 (control positive) revealed degeneration and necrosis of spermatogoneal cells lining seminiferous tubules with interstitial edema and (Figs. 2) vacuolation of leydig cells. Meanwhile, testis of rats from groups 3 \& 4 Hibiscus sabdariff calyx extrac $(100,200 \mathrm{mg} / \mathrm{kg})$ showed no histopathological alterations (Figs. 3\& 4). However, some examined sections from group 5 Ceratonia silique extract $(100 \mathrm{mg} / \mathrm{kg})$ revealed slight degeneration of spermatogoneal cells 
lining seminiferous tubules (Fig. 5), whereas, other sections from this group as well as from group 6 Ceratonia silique extract $(200 \mathrm{mg} / \mathrm{kg}$ ) revealed no histopathological alterations (Figs. 6).The results agreement with Amaral et al., (2009) cleared several experimental studies in diabetic animals have recorded episodes of testicular dysfunction and sperm abnormalities .Also studies have indicated that diabetic disease caused testicular dysfunctions including reproductive hormone changes, sperm disorders and sperm decrease, all were directly related to testicular health (Agarwal et al., 2012 and Aitken et al., 2014). Md Idris et al., (2013) histological study showed that degenerative changes such as disorganization and degeneration of seminiferous tubules and defection in sertoli cells and spermatogonia occurred in the testis of diabetic rats. While, in models of diabetic rats, Hibiscus sabdariff extrac( HSE) has potential to prevent sperm and testicular alteration. Another study by Giacco and Brownlee, (2010)revealed that protective effects of carob extract can be due to free radical scavenging properties, which leads to a reduction in testicular oxidative damage. Budin et al.,(2018)Confirmed that, the histological observation showed morphological alteration of the testis in the DM- rat, which was impeded by Supplements of Hibiscus sabdariffa polyphenol-rich extract (HPE) from. In summary, supplementation with (HPE) is capable of preventing oxidant injury of diabetic rat testis.

\section{Conclusion}

In conclusion, oral administration of Hibiscus sabdariffa calyx and Ceratonia silique aqueous extracts to rats with diabetes exhibited anti-diabetic, anti-hyperlipidemic and anti-oxidant activities. These findings indicate the likelihood of use of Hibiscus sabdariffa calyx and Ceratonia silique plant for treating diabetic Infertility patients due to the strong anti-oxidant and antidiabetic effects. 
Table (1): Active component of aqueous extract of Hibiscus sabdariffa calyx and Ceratonia silique

\begin{tabular}{|c|c|c|}
\hline Camples & $\begin{array}{c}\text { Total phenols } \\
\text { ( } \mathbf{m g} / \mathbf{g})\end{array}$ & $\begin{array}{c}\text { Total Flavonoids } \\
(\mathbf{m g} / \mathbf{g})\end{array}$ \\
\hline $\begin{array}{c}\text { Concentrated Hibiscus } \\
\text { sabdariff calyx extract }\end{array}$ & 6.04 & 4.61 \\
\hline $\begin{array}{c}\text { Diluted Hibiscus sabdariff } \\
\text { calyx extract }\end{array}$ & 3.02 & 2.31 \\
\hline $\begin{array}{c}\text { Concentrated Ceratonia } \\
\text { silique extract }\end{array}$ & 1.45 & 1.06 \\
\hline $\begin{array}{c}\text { Diluted Ceratonia silique } \\
\text { extract }\end{array}$ & 0.73 & 0.53 \\
\hline
\end{tabular}

Table (2): Effect of two dosage of aqueous extract of Hibiscus sabdariffa calyx and Ceratonia silique on nutritional parameters of rats suffering diabetes.

\begin{tabular}{|c|c|c|c|}
\hline $\begin{array}{ll} & \text { Parameters } \\
\text { Groups }\end{array}$ & FI (g/day) & FER & BWG (\%) \\
\hline Control Negative & $19.45^{\mathrm{a}} \pm 0.43$ & $0.16^{\mathrm{a}} \pm 0.03$ & $58.91^{\mathrm{a}} \pm 11.89$ \\
\hline Control Positive & $19.62^{\mathrm{a}} \pm 0.21$ & $0.14^{\mathrm{a}} \pm 0.04$ & $57.49^{\mathrm{a}} \pm 15.34$ \\
\hline HSE (100mg/kg) & $19.44^{\mathrm{a}} \pm 0.30$ & $0.12^{\mathrm{a}} \pm 0.02$ & $53.17^{\mathrm{a}} \pm 13.88$ \\
\hline HSE (200mg/kg) & $19.76^{\mathrm{a}} \pm 0.51$ & $0.14^{\mathrm{a}} \pm 0.05$ & $51.18^{\mathrm{a}} \pm 15.48$ \\
\hline CSE (100mg/kg) & $19.39^{\mathrm{a}} \pm 0.42$ & $0.13^{\mathrm{a}} \pm 0.04$ & $48.41^{\mathrm{a}} \pm 13.87$ \\
\hline CSE $(200 \mathrm{mg} / \mathrm{kg})$ & $19.16^{\mathrm{a}} \pm 0.68$ & $0.13^{\mathrm{a}} \pm 0.02$ & $44.66^{\mathrm{a}} \pm 7.19$ \\
\hline LSD & 0.67 & 0.05 & 19.68 \\
\hline
\end{tabular}

Means with different letters in each column are significantly different at $\mathrm{p}<0.05$.

SD:Standard Deviation. 
Table (3): Effect of two dosage of aqueous extract of Hibiscus sabdariffa calyx and Ceratonia silique on Lipid profile of rats suffering diabetes.

\begin{tabular}{|c|c|c|c|}
\hline Groups Parameters & HDL & LDL & VLDL \\
\hline Control Negative & $50.60^{\mathrm{a}} \pm 1.51$ & $19.52^{\mathrm{d}} \pm 8.47$ & $14.39^{\mathrm{d}} \pm 1.22$ \\
\hline Control Positive & $39.03^{\mathrm{d}} \pm 3.16$ & $153.62^{\mathrm{a}} \pm 23.88$ & $28.03^{\mathrm{a}} \pm 2.09$ \\
\hline HSE (100mg/kg) & $45.77^{\mathrm{c}} \pm 1.50$ & $117.72^{\mathrm{b}} \pm 17.75$ & $20.89^{\mathrm{b}} \pm 1.63$ \\
\hline HSE (200mg/kg) & $47.55^{\mathrm{bc}} \pm 1.86$ & $98.87^{\mathrm{b}} \pm 6.21$ & $17.31^{\mathrm{c}} \pm 1.06$ \\
\hline CSE (100mg/kg) & $49.02^{\mathrm{ab}} \pm 1.47$ & $104.22^{\mathrm{b}} \pm 15.94$ & $19.81^{\mathrm{bc}} \pm 2.23$ \\
\hline CSE (200mg/kg) & $48.65^{\mathrm{abc}} \pm 1.12$ & $59.38^{\mathrm{c}} \pm 9.55$ & $18.54^{\mathrm{bc}} \pm 1.12$ \\
\hline LSD & 2.81 & 22.21 & 2.42 \\
\hline
\end{tabular}

Means with different letters in each column are significantly different at $\mathrm{p}<0.05$.

SD:Standard Deviation.

Table (4): Effect of two dosage of aqueous extract of Hibiscus sabdariffa calyx and Ceratonia silique on Lipid profile\& Glucose of rats suffering diabetes.

\begin{tabular}{|c|c|c|c|}
\hline Groups Parameters & T.C & T.G & Glucose \\
\hline Control Negative & $84.50^{\mathrm{d}} \pm 7.24$ & $71.93^{\mathrm{d}} \pm 6.05$ & $130.6^{\mathrm{d}} \pm 12.74$ \\
\hline Control Positive & $220.69^{\mathrm{a}} \pm 21.72$ & $140.18^{\mathrm{a}} \pm 10.43$ & $345.77^{\mathrm{a}} \pm 15.87$ \\
\hline HSE (100mg/kg) & $184.38^{\mathrm{b}} \pm 19.64$ & $104.44^{\mathrm{b}} \pm 8.18$ & $265.65^{\mathrm{b}} \pm 34.79$ \\
\hline HSE (200mg/kg) & $163.74^{\mathrm{b}} \pm 7.56$ & $86.57^{\mathrm{c}} \pm 5.31$ & $175^{\mathrm{c}} \pm 7.24$ \\
\hline CSE (100mg/kg) & $173.04^{\mathrm{b}} \pm 18.08$ & $99.05^{\mathrm{bc}} \pm 11.13$ & $239.67^{\mathrm{b}} \pm 18.72$ \\
\hline CSE (200mg/kg) & $126.57^{\mathrm{c}} \pm 8.47$ & $92.72^{\mathrm{bc}} \pm 5.58$ & $177.42^{\mathrm{c}} \pm 11.93$ \\
\hline LSD & 22.42 & 12.07 & 28.25 \\
\hline
\end{tabular}

Means with different letters in each column are significantly different at $\mathrm{p}<0.05$.

SD:Standard Deviation. 
Table (5): Effect of two dosage of aqueous extract of Hibiscus sabdariffa calyx and Ceratonia silique on Serum Testosterone, Folicle Stimulating Hormone, Lutenizing Hormone and Prolactin of rats suffering diabetes.

\begin{tabular}{|c|c|c|c|c|}
\hline $\begin{array}{c}\text { Parameters } \\
\text { Groups }\end{array}$ & T.T(ng/ml) & FSH(mlu/ml) & LH(mlu/ml) & PRL.(ng/ml) \\
\hline Control Negative & $\begin{array}{c}14.75^{\mathrm{a}} \\
\pm 2.90\end{array}$ & $4.49^{\mathrm{a}} \pm 0.55$ & $27.23^{\mathrm{a}} \pm 2.89$ & $0.44^{\mathrm{c}} \pm 0.05$ \\
\hline Control Positive & $0.87^{\mathrm{c}} \pm 0.09$ & $0.66^{\mathrm{e}} \pm 0.09$ & $4.01^{\mathrm{e}} \pm 0.64$ & $7.29^{\mathrm{a}} \pm 1.29$ \\
\hline HSE (100mg/kg) & $2.08^{\mathrm{c}} \pm 0.73$ & $1.03^{\mathrm{de}} \pm 0.15$ & $6.04^{\mathrm{e}} \pm 1.20$ & $1.08^{\mathrm{c}} \pm 0.37$ \\
\hline HSE (200mg/kg) & $7.21^{\mathrm{b}} \pm 1.34$ & $2.18^{\mathrm{c}} \pm 0.24$ & $13.13^{\mathrm{c}} \pm 1.51$ & $3.60^{\mathrm{b}} \pm 0.67$ \\
\hline CSE (100mg/kg) & $2.19^{\mathrm{c}} \pm 0.65$ & $1.42^{\mathrm{d}} \pm 0.17$ & $8.47^{\mathrm{d}} \pm 1.06$ & $1.12^{\mathrm{c}} \pm 0.32$ \\
\hline CSE (200mg/kg) & $5.50^{\mathrm{b}} \pm 0.53$ & $2.85^{\mathrm{b}} \pm 0.16$ & $17.12^{\mathrm{b}} \pm 0.96$ & $2.76^{\mathrm{b}} \pm 0.30$ \\
\hline $\mathbf{~ L S D ~}$ & 2.05 & 0.41 & 2.31 & 0.95 \\
\hline
\end{tabular}

Means with different letters in each column are significantly different at $\mathrm{p}<0.05$.

SD:Standard Deviation.

T.T: Testosterone

FSH: Folicle Stimulating Hormone

LH: Lutenizing Hormone

PRL: Prolactin 
Histopathological examination of pancreas:

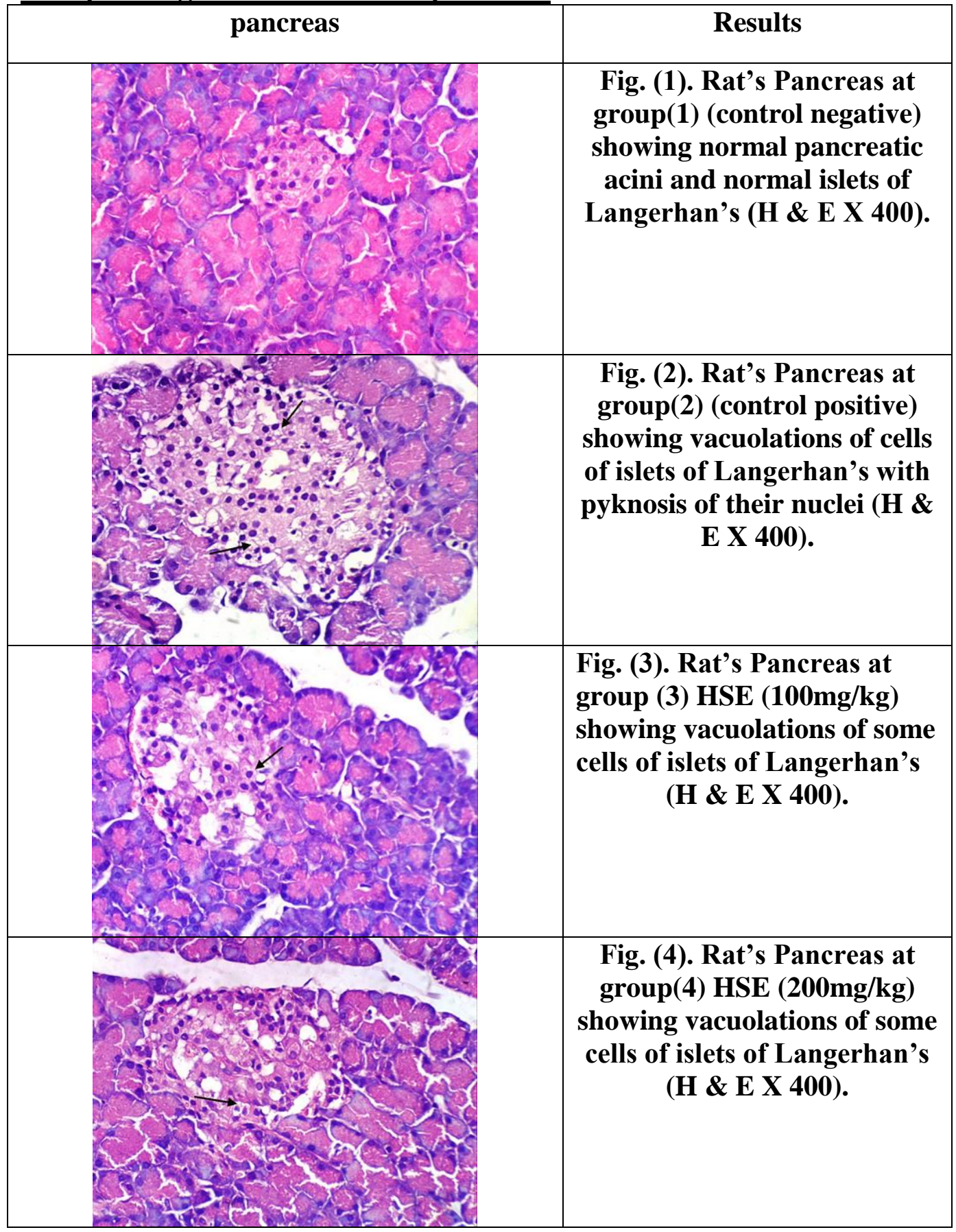




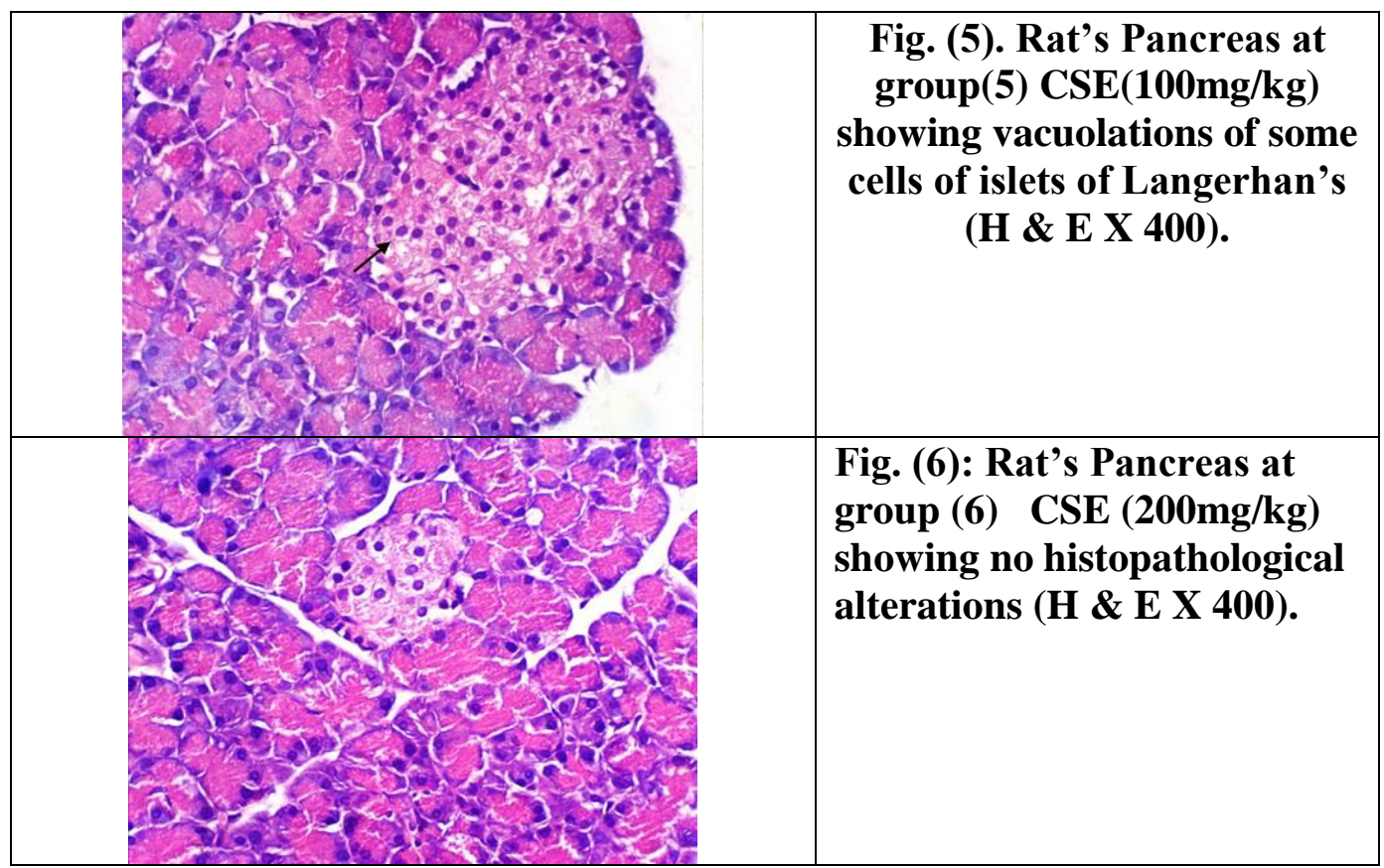

Histopathologicalexamination of Testis:

\begin{tabular}{|c|l|}
\hline Testis & \multicolumn{1}{c|}{ Results } \\
\hline & $\begin{array}{l}\text { Fig. (1). Rat's testis at group(1) (control } \\
\text { negative) showing the normal } \\
\text { histological structure of seminiferous } \\
\text { tubule with normal spermatogoneal cells } \\
\text { and complete spermatogenesis } \\
\text { (H \& E X 400). }\end{array}$ \\
\hline & $\begin{array}{l}\text { Fig. (2). Rat's testis at group(2) } \\
\text { (control positive) showing degeneration } \\
\text { and necrosis of spermatogoneal cells } \\
\text { lining seminiferous tubules with } \\
\text { interstitial edema and vacuolation of } \\
\text { leydig cells (H \& E X 400). }\end{array}$ \\
&
\end{tabular}




\begin{tabular}{|c|c|}
\hline Q & $\begin{array}{l}\text { Fig. (3). Rat's testis at group (3) HSE } \\
(100 \mathrm{mg} / \mathrm{kg}) \text { showing no histopathological } \\
\text { alterations (H \& E X 400). }\end{array}$ \\
\hline 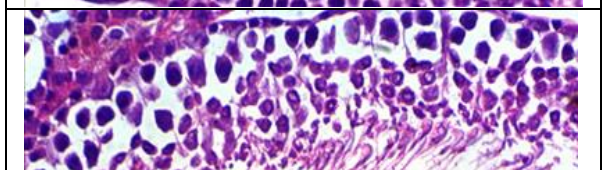 & $\begin{array}{l}\text { Fig. (4). Rat's testis at group (4) HSE } \\
(200 \mathrm{mg} / \mathrm{kg}) \text { showing no histopathological } \\
\text { alterations(H \& E X 400). }\end{array}$ \\
\hline & $\begin{array}{l}\text { Fig. (5). Rat's testis at group (5) } \\
\text { CSE(100mg/kg) showing slight } \\
\text { degeneration of spermatogoneal cells } \\
\text { lining seminiferous tubules } \\
\text { (H \& E X 400). }\end{array}$ \\
\hline 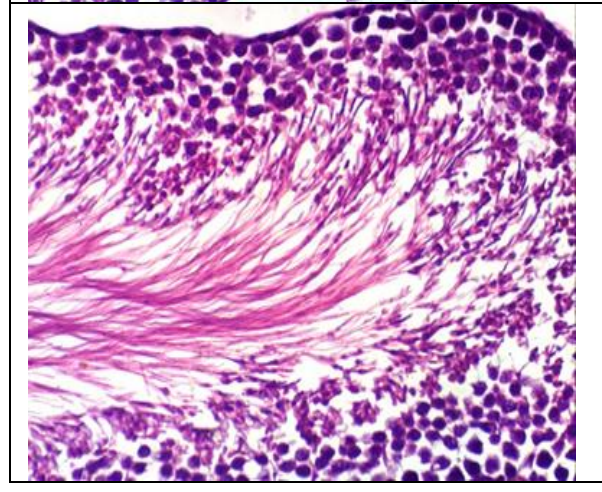 & $\begin{array}{l}\text { Fig. (6). Rat's testis at group (6) CSE } \\
(200 \mathrm{mg} / \mathrm{kg}) \text { showing no histopathological } \\
\text { alterations (H \& E X 400). }\end{array}$ \\
\hline
\end{tabular}




\section{References}

-Agarwal, A.;Aponte-Mellado, A.; Premkumar, B.J.;Shaman ,A and Gupta ,S.(2012). The effects of oxidative stress on female reproduction: a review. Reprod Biol Endocrinol,( 10): 49-80.

-Aitken, R.J.; Smith ,T.B.;Jobling, M.S.;Baker, M.A and De Iuliis ,G.N.(2014). Oxidative stress and male reproductive health. Asian J Androl, 16(1): 31-38.

-Amaral ,S.;Mota, P.C.; Lacerda, B.; Alves, M.;Pereira, M.L and Oliveira, P. S. (2009). Testicular mitochondrial alterations in untreated streptozotocininduced diabetic rats. Mitochondrion ,(9):41-50.

-Andallu, B.;Vinay Kumar, A.V and Varadacharyulu, N.C.(2009). Lipid abnormalities in streptozotocin-diabetes: amelioration by Morus indica L. cv Suguna leaves. Int J Diabetes Dev Countries .(29):123-128.

-Ashok, D.C.; Shrimant, N.P; Panadeep, M.G. and Akalpita, U.A. (2007): Optimization of alloxan dose is essential to induce stable diabetes mellitus for long period. Asian J. Biochem., 2(6): 402-408.

-Azadeh.; Shabnam Mohammadi.; Alireza Fazel.; Mohammad Soukhtanloo.; pourA.M and Farimah Beheshti.(2018). Effects of Carob (Ceratonia siliqua) on Sperm Quality, Testicular Structure, Testosterone Level and Oxidative Stress in Busulfan-Induced Infertile Mice. Pharmaceutical Sciences. 24, 104-111.

-Ballester, J.;Muñoz, M.C.;Domínguez, J.; Rigau ,T.; Guinovart, J.J and Rodríguez-Gil, J.E.(2004). Insulin-dependent diabetes affects testicular function by FSH-and LH-linked mechanisms.J Androl ,(25):706-719.

-Bancroft ,J.D.; Suvarna,K and Layton,C.( 2012). Bancroft's theory and practice of histological techniques. 7th ed. E book ISBN. 978-0-7020-50325039.

-Budin, S.B.;Wan Zafirah, A.R.; Jubaidi,F.F.; Nur Liyana ,Y.M.; Taib, I.S.;Satirah Zainalabidin.(2018). Roselle (Hibiscus sabdiriffa) PolyphenolRich Extract Prevents Testicular Damage of Diabetic Rats. Journal of Applied Pharmaceutical Science 8(02), pp 065-070.

-Chapman, D.G.; Castilla,R. and Champell, J.A.(1959).Evaluation of protein efficiency ratio ,Can.J.Biochem.Physiol.,37:679-686. 
-Fried wald, W. T., Leve, R. I. and Fredrickson‘ D. S. (1972). Estimation of the concentration of low-density lipoprotein separation by three different methods . Cli. Chem.; 18: 499-502.

-Gamboa-Gómez ,C.I.; Simental-Mendía， L.E.;González-Laredo， R.F.; Alcantar-Orozco, E.J.;Monserrat-Juarez, V.H.; Ramírez-España, J.C.; Gallegos-Infante, J.A.;Moreno-Jiménez,M.R and Rocha-Guzmán ,N.E. (2017). In vitro and in vivo assessment of anti-hyperglycemic and antioxidant effects of Oak leaves (Quercus convallata and Quercus arizonica) infusions and fermented beverages. Food Research International 102:690_699.

-Giacco ,F and Brownlee ,M.(2010). Oxidative stress and diabetic complications. Circ Res, 2010; 107(9): 1058-1070.

-Hanhineva, K.; Torronen ,R.; Bondia-Pons, I.;Pekkinen ,J.; Kolehmainen, $M$ and Mykkonen, H. (2010). Impact of dietary polyphenols on carbohydrate metabolism. Int J Mol Sci .(11):1365-1402.

-Hirunpanich V.;Utaipat ,A.;Morales, N.P.; Bunyapraphatsara, N, Sato ,H and Herunsale, A. (2006) . Hypocholesterolemic and antioxidant effects of aqueous extracts from the dried calyx of Hibiscus sabdariffa L. in hypercholesterolemic rats. J. Ethnopharmacol;103:252-260.

-Inês Da ,R.C.; Bernd Bonnlaender.; Hartwig Sievers.;Ivo Pischel and Michael Heinrich.(2014). Hibiscus sabdariffa L. - A phytochemical and pharmacological review. Food Chemistry. 165 , 424-443.

-International Diabetes Federation. (2016). International Diabetes Federation. IDF Diabetes Atlas. Brussels: International Diabetes Federation.

-Joanne,S.(2013). Fiber and prebiotics: mechanisms and health benefits. Nutrients(5):1417-1435.

-Joyeux,M.A.; Lobestein,R and Morier ,F. (1995). Comparative antilipoperoxidant,anti-necrotic and scavenging potencies of terpenes and bioflavones from gingko and some flavonoids.Planta Med.,61:126-129.

-Kasote, D.M.;Katyare ,S.S.;Hegde, M.Vand Bae ,H. (2015). Significance of antioxidant potential of plants and its relevance to therapeutic applications. International Journal of Biological Sciences 11(8):982_991.

-Kim ,Y.;Keogh, J.B and Clifton, P.M.(2016). Polyphenols and Glycemic Control. Nutrients, 8(1): 17.

-Lopes-Virella, M. F.,Stone, S.,Ellis, S. and Collwellm, J. A. (1977).Cholesterol determination in high-density lipoproteins separated by three different methods. Clin. Chem.; 23 (5): 882-893. 
-Md Idris, M.H.;Budin, S.B.; Mohamed, J and Osman, M.(2012). Protective role of Hibiscus sabdariffa calyx extract against streptozotocin induced sperm damage in diabetic rats. EXCLI J, (11): 659-669.

-Md Idris,M.H.; Budin,S.B.; Mohamad Osman and Jamaludin Mohamed. ( 2013). Hibiscus Sabdariffa L. UKMR-2 AS A Protective Agent Against Sperm and Testicular Damage IN Streptozotocin Induced Diabetic Rats. The Open Conference Proccedings Journal .( 4). P 96.

-Mahmoud ,Y.I.(2012). Effect of extract of Hibiscus on the ultrastructure of the testis in adult mice. Acta Histochem ,114:342-348.

-Marghoob,H and Abdelmarouf,M. (2016). In vivo evaluation of antidiabetic hypolipidemic, antioxidative activities of Saudi date seed extract on streptozotocin induced diabetic rats, J. Clin. Diagn. Res. 10, FF06-FF12.

-Mohammadi ,S.; Safari, F.; Seyedi, Z.; Seyed H, E.;Karimi, F and Mohammadi, M.(2016). Effect of different doses of $\mathrm{N}$-acetyl cysteine on biochemical and histopathological parameters in kidney of formalintreated.J Kansai Med Univ.23(5):607-617.

-Mokhtari, M .; Sharifi, E and Azadian ,S.H.( 2012). The effects of hydro alcoholic extract of Ceratonia siliqua L. seeds on pituitary - testis hormones and spermatogenesis in rat. Advances in Environmental Biology, 6(10): 27782783.

-Moundipa FP, Kamtchouing P, Koueta N, Tantchou J, Foyang NP, Mbiapo FT (1999). Effects of aqueous extracts of Hibiscus macranthus and Basella alba in mature rat testis function. J. Ethnopharmacol. 65: 133-139.

-Neeru Vasudeva and Sharma, S. K.(2008). Biologically Active Compounds from the Genus Hibiscus. Pharmaceutical Biology .. 46,.. 3), 145-153.

-Nwabufo,C.K and Olusanya,O.(2017). Biochemical Effect of Hibiscus sabdariffa Calyx Extracts on the Reproductive Hormones of Male Wistar Rat. Advances in Applied Science Research,8(2):38-41.

-Ochani, P. C and Mello, P. (2009). Antioxidant and antihyperlipidemic activity of Hibiscus sabdariffa Linn. leaves and calyces extracts in rats. Indian Journal of Experimental Biology, 47(4), 276-282.

- Orisakwe ,O.E.; Husaini, D.C and Afonne ,O.J.(2004). Testicular effects of sub- chronic administration of Hibiscus sabdariffa calyx aqueous extract in rats. Reprod Toxicol,18:295-8.

-Peng, C. H.; Chyau, C. C.; Chan, K. C.; Chan, T. H.;Wang, C. J and Huang, C. N. (2011).Hibiscus sabdariffa polyphenolic extract inhibits 
hyperglycemia, hyperlipidemia, and glycation-oxidative stress while improving insulin resistance. Journal of Agricultural and Food Chemistry, 59(18), 99019909.

-Puro, K.;Sunjukta ,R.; Samir, S.; Ghatak ,S.; Shakuntala ,I and Sen ,A.(2014). Medicinal Uses of Roselle Plant (Hibiscus sabdariffa L.): A Mini Review. Indian J Hill Fmg, 27(1): 81-90.

-Qasem,M.A.; Mohamed ,I. N.; Aditya Arya.;Abdulsamad Alsalahi and Soher, N.J..(2018). Evaluation of the glycemic effect of Ceratonia siliqua pods (Carob) on a streptozotocin-nicotinamide induced diabetic rat model. PeerJ 6:e4788.

-Reeves, P. G.; Nielsen, F. H. and Fahmy, G. C. (1993). AIN-93 purified diets for laboratory rodents: Final report of the American Institute of Nutrition ad hoc writing committee on the reformulation of the AIN-76A rodent diet. J. Nutr.; 123(11):1939-1951.

-Rejeb, M.N. (1995) . Le caroubier en Tunisie: Situations et perspectives d'amélioration. Dans Quel avenir pour l'amélioration des plantes? Edit. Aupelfuref. John Libbey Eurotext, Paris, 79-85.

-Rtibi, K.;Jabri ,M.A.; Selmi ,S.;Souli ,A.; Sebai, H and El-Benna, J .(2015). Gastroprotective effect of carob (Ceratonia siliqua L.) against ethanolinduced oxidative stress in rat. BMCComplementary AlternMed. (15):292.

-Rtibi, K.;Selmi, S.; Grami, D.;Saidani ,K.;Sebai, H and Amri ,M.(2017). Ceratonia siliqua L. (immature carob bean)inhibits intestinal glucose absorption, improves glucose tolerance and protects against alloxan-induced diabetes in rat. J Sci Food Agric.;97(8):2664-70.

-Schettler, G. and Nussel,E. (1975): Arb.Med.Soz.Med.Prav.Med.,10:25.

-Si ,L.Y.;Ali, S.A.; Latip ,J.;Fauzi ,N.M.; Budin, S.B and Zainalabidin ,S.(2017). Roselle is cardioprotective in diet-induced obesity rat model with myocardial infarction. Life Sci, 191: 157-165.

-Singleton,L.V.;Rudolf Orthofer and Lamuela-Raventos,R.M. (1999). Analysis of total phenols and other oxidation substrates and antioxidants by means of folin-ciocalteu reagent.Methods in Enzymology,299c:152-178.

-Steel, R. G. and Torri, J. H. (1980). Principal and Procedures of Statistical, Biometrical Approach. Pbl. Mc Grew Hill Book Company. $2^{\text {nd }}$ ed. New York, U.S.A.

-Tietz ,N.W.(1995). Clinical Guide to Laboratory Tests. 3rd ed., W. B. Saunders Company; Philadelphia .1-997. 
-Trinder,P.(1969).Enzymatic determination of blood glucose. Ann. Clin. Biochem,6:24-27.

-Tsai, P.J.; McIntosh, J.;Pearce, P.; Camden, B and Jordan, B.R.(2002).Anthocyanin and antioxidant capacity in Roselle (Hibiscus sabdariffa L.) extract. Food Res Int ,(35):351-356.

-Tzu, L.L.; Hui, H.L.;Chang, C.C.; Ming, C.L.; Ming ,C.C and Chau, J.W. (2007). Hibiscus sabdariffa L. extract reduces serum cholesterol in men and women. Nutrition Research. 27: 140-145.

-Ubani ,C.S.; Joshua ,P.E and Oraeki ,A.N.(2010). Influence of aqueous extract of Hibiscus sabdariffa calyces on lipid profile of phenobarbitone induces wistar albino rats. J. Pharm Res ,(3):319-324.

-Uotila, M.; Ruoslathi, E and Envall, E.( 1981). Two-site sandwich enzyme immunoassay with monoclonal antibodies to human alphafetoprotein. J Immunol Methods. 42:11- 15.

-Wilke,T.J and Utley,D.J.(1987).Total testosterone,free androgenic index and calculated free testosterone by analog RIA method.Clin Chem.,33:1372-1375.

-Yang, M. Y.; Peng, C. H.; Chan, K. C.; Yang, Y. S.;Huang, C. N and Wang, C. J. (2010). The hypolipidemic effect of Hibiscus sabdariffa polyphenols via inhibiting lipogenesis and promoting hepatic lipid clearance. Journal of Agricultural and Food Chemistry, 58(2), 850-859. 


\section{الملخص العربى}

تأثير المستخلص المائى للكركدية والخروب على الهرمونات التتاسلية لذكور الجرذان المصابة بمرض السكرى

تم دراسة تأثير المستخلص المائي لكلاً من الكركديه والخروب على المأخوذ الغذائي ، ومعدل كفاءة الغذاء ، وزيادة وزن الجسم ، ودهون الدم ، وجلوكوز الدم ، وهرمونات الخصوبة في سيرم الجرذان المصابة بداء السكري. نم تقسيم ثلاثثن من الجرذان البالغة من نوع (Sprague Dawley) إلى 7 مجموعات متساوية بشكل عشوائي. المجموعة (1) تم تغذيتها على نظام غذائي أساسي (مجموعة ضابطة سالبة) ، بينما تم تغذية عدد (Yo) من الجرذان الأخرى على نظام غذائي أساسي ثم إصابتها

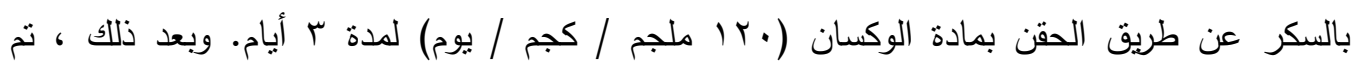
الاحتفاظ بمجموعة (Y) من مرضى السكري (كمجموعة ضابطة موجبه) وأعطيث المجموعات الأربع الأخرى عن طريق الفم r مل من المستخلص المائي لكلاً من الكركديه والخروب المكتف والمخفف منف

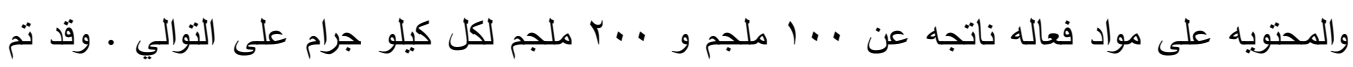
جمع عينات الدم لفصل السيرم المستخدم في التحاليل البيوكيميائية. واخذت عينات من البنكرياس والخصية للفحص الهستوباثولوجي • وقد وجدت اعلى نسبة من المواد الفعاله موجوده في المستخلص المائي المركز للكركديه. أوضحت النتائج أن الإعطاء الفموي للمستخلصات المائية من الكركديه والخروب للجرذان المصابة بمرض السكري بعدم وجود فروق معنويه فى المأخوذ الغذائي ومعدل كفاءة الغذاء زيادة وزن الجسم وانخفاض مستويات السيرم من الكوليسترول الكلي (TC) والدهون الثلاثية (TG) ، البروتينات الدهنية منخفضة الكثافة (LDL-c) ، البروتينات الدهنية منخفضة الكثافة جدًا (VLDL-c) ، والبرولاكتين وزيادة في البرونينات الدهنية عالية الكثافة (HDL-c). وحدوث انخفاض في جلوكوز الدم عن طريق تتاول المستخلصات المائية من الكركديه والخروب. كما زادت هرمونات الخصوبة في السيرم من Testosterone, Folicle Stimulating Hormone, Luteinizing Hormone في الجرذان المصابة بمرض السكري. هذه النتائج أوضحت التأثير الإيجابي للمستخلصات المائية من الكركديه والخروب في الفحص الههتوباتولوجي للبنكرياس والخصية . وتتبير هذه النتائج إلى إمكانية استخدام نبات الكركديه والخروب لتحسين هرمونات الخصوبة للمرضى المصابين بداء السكري. الكلمات المفتاحية: الكركديه ، الخروب ، هرمونات الخصوبة ، مرض السكري ، دهون الام ، مضادات

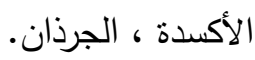

